\title{
AÇÃO COLETIVA E DEFESA DE DIREITOS NAS COMUNIDADES TRADICIONAIS DE FUNDO E FECHO DE PASTO DE SALOBRO E JACURUTU, OESTE DA BAHIA // Mirna Silva Oliveira ${ }^{1}$
}

\section{Palavras-chave}

conflitos de terra / fechos e fundos de pasto / direitos territoriais / luta por direitos / arenas públicas

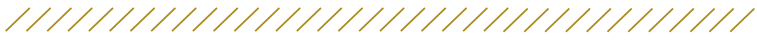

\section{Sumário}

\section{Introdução}

2 Marcha para o Oeste

3 A invasão dos Gerais

4 O processo de organização política

$5 \quad 0$ desrespeito aos costumes

6 As lógicas de justificação e de legitimação dos direitos

$7 \quad 0$ acionamento do poder judiciário e a lógica de ação dual

80 problema público

9 Considerações finais

10 Referências

\section{Resumo}

O presente artigo analisa o lugar do direito no processo de emergência e organização política das comunidades de fecho e fundo de pasto de Jacurutu e Salobro, no Oeste da Bahia, na luta pela preservação de seus modos de vida frente as ameaças de expropriação e grilagem. Para tanto, utilizou-se como referência a teoria das arenas públicas de Daniel Cefaï e deu-se destaque à forma como os sujeitos organizaram suas experiências de contato com a grilagem; as múltiplas motivações para o engajamento, e a forma como o conflito foi se constituindo como um problema público. 0 estudo apontou que, por um longo tempo, a resistência das comunidades ao processo de expropriação foi sendo constituída nas relações cotidianas, impulsionada pela noção de respeito aos costumes e tendo como marca o caráter predominantemente local. A partir de 2006, com o apoio da Comissão Pastoral da Terra, do Sindicato de TrabaIhadores Rurais e, mais tarde, da Associação de Advogados de Trabalhadores Rurais no Estado da Bahia, as comunidades passaram a se articular e a se inserir em espaços de publicização, organização, denúncia, negociação e reivindicação que foram se constituindo como uma arena pública e configurando o conflito como um problema público. Nesse processo, verificou-se que a noção de defesa dos direitos - seja costumeiro e/ou positivo - assumiu papel fundamental na caracterização do confronto em ambas as fases do conflito, contribuindo tanto para o engajamento dos sujeitos como para o reconhecimento do confronto como um problema público.

\footnotetext{
1 A autora é graduada em Direito pela Universidade Estadual de Feira de Santana e mestre pelo Programa de Ciências Sociais em Desenvolvimento, Agricultura e Sociedade da Universidade Federal Rural do Rio de Janeiro. É membro da Associação de Advogados/as de Trabalhadores/as Rurais no Estado da Bahia (AATR) e atualmente trabalha como advogada e assessora jurídica do Instituto Regional da Pequena Agropecuária Apropriada (IRPAA), da Comissão Pastoral da Terra (Regional Centro Norte da Bahia) e do Sindicato de Trabalhadores Rurais de Remanso.
} 


\section{COLLECTIVE ACTION AND RIGHTS DEFENSE IN SALOBRO AND JACURUTU TRADITIONAL PASTURE COMMUNITIES IN WESTERN}

\section{BAHIA // Mirna Silva Oliveira}

\section{Keywords}

land conflicts / communities of pasture background / territorial rights / right struggle / public arenas

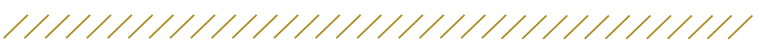

\section{Abstract}

This article analyzes the place of law in the struggle for preservation of traditional ways of life of pasture communities in Western Bahia (Jacurutu and Salobro). In order to analyse the political organization of these communities, we used the theory of public arenas by Daniel Cefaï, highlighting the way the members of the communities organized their experiences of contact with land grabbers; to the multiple motivations for engagement and the way in which the conflict was being constructed as a public issue. The study found that, for a long time, the resistance that the communities faced during the process of expropriation was being incorporated in everyday relationships, driven by the notion of respect for customs and having a predominantly local character. From 2006, with the support of Pastoral Land Commission, Rural Workers' Union, and later of lawyers of the of Rural Workers Lawyers Association in the State of Bahia, the communities started to articulate and to insert themselves in public actions, organization, complaint, negotiation that became to be the public arena, which configured the conflict as a public problem. In this process, we found that the notion of customary and/or positive rights defense played a key role in the characterization of the confrontation during both phases of the conflict, contributing both to the engagement between the subjects as well as for the recognition of the conflict as a public issue. 


\section{Introdução}

O presente artigo tem como objetivo analisar o lugar do direito no processo de emergência e organização política das Comunidades Tradicionais de Fundo e Fecho de Pasto de Salobro e Jacurutu, (Oeste da Bahia) na luta contra a grilagem e pela preservação de seus modos de vida. Os Fechos e Fundos de Pasto são comunidades rurais encontradas especialmente nas regiões do cerrado e da caatinga baiana, que desenvolveram um modo de vida baseado na cultura do pastoreio e na articulação entre terras e recursos naturais de uso comum (usadas para criação de animais soltos e para o extrativismo) e glebas pertencentes a cada unidade familiar (usadas para moradia e agricultura). Através da identidade de fundo e fecho de pasto, tais comunidades vêm se organizando, nas últimas décadas, para reivindicar o reconhecimento da especificidade de seus modos de vida e do direito aos territórios que tradicionalmente ocupam, ameaçados pelo avanço do agronegócio e pelos projetos de infraestrutura e produção de energia impulsionados pelo Estado.

O trabalho, resultado de pesquisas da autora nos anos 2013 e 2014, durante a elaboração de sua dissertação de mestrado, situa-se num contexto de intensificação dos conflitos fundiários na região Oeste da Bahia, inserida na MATOPIBA. ${ }^{2}$ São conflitos latentes desde a década de 1970, com o avanço do agronegócio sobre áreas ocupadas por comunidades tradicionais "geraizeiras", ribeirinhas, quilombolas e de "fechos e fundos de pasto", mas que ganharam novo fôlego nos últimos anos. Neste cenário, múltiplas formas de resistência vêm sendo construídas. No entanto, há poucos estudos sobre tais experiências e, em especial, sobre as Comunidades de Fecho e Fundo de Pasto dessa região. Ademais, os raros trabalhos existentes pouco exploram a sua dimensão jurídica - que nesta pesquisa assume lugar central.

A relação entre movimentos sociais e direito, apesar de sempre presente na história das lutas sociais no Brasil e no mundo, rendeu poucas preocupações acadêmicas. De acordo com Agrikolansky (2010, como

2 Divisão geográfica formada por parcelas dos estados do Maranhão, Tocantins, Piauí e Bahia, mapeada pelas políticas de planejamento estatal para a grande agricultura como a mais nova fronteira agrícola do Brasil citado em Medeiros, 2012, p. 02), "as abordagens dominantes da ação coletiva dão ênfase principalmente ao caráter não institucional das estratégias empregadas pelos que protestam", de modo que "o direito como repertório de ação coletiva" tem sido pouco estudado. Segundo Medeiros (2012, p. 02), a sua dimensão jurídica tem sido tratada "como algo dado, e não como expressão política da própria emergência de novos atores na cena política".

Compartilhando dessa perspectiva, parte-se do pressuposto de que não é possível entender o processo de organização política das comunidades tradicionais de fundo e fecho de pasto objeto de estudo sem explorar a sua dimensão jurídica. Tal entendimento foi sendo reforçado durante a pesquisa, ao se perceber que o direito assumia um papel central na mediação da relação entre os sujeitos no conflito, pois foi a partir da noção de que "estavam dentro de seus direitos" que os sujeitos justificavam suas ações e buscavam legitimar seus pleitos. Para tanto, faziam uso recorrente tanto do direito consuetudinário como do direito positivo (ao mesmo tempo em que reivindicavam o respeito aos costumes nas relações cotidianas de conflito, também disputavam o reconhecimento da legitimidade e legalidade dos mesmos perante 0 Estado); dialogavam progressivamente com categorias reconhecidas legalmente (tais como as categorias fundo e fecho de pasto e terras devolutas), e se constituíam politicamente a partir do seu uso.

Buscar-se-á, então, analisar, neste artigo, o processo de organização política das comunidades de Salobro e Jacurutu para enfrentamento da grilagem de terras desde a década de 1980. Para tanto, utilizou-se como referência a teoria das arenas públicas de Daniel Cefaï (2009), que analisa a emergência dos movimentos sociais a partir da dinâmica de enquadramento, justificação e construção de problemas públicos.

A partir do entendimento de que a ação coletiva constitui "uma arquitetura móvel de contextos de sentido", Cefaï (2009, p. 28) tenta problematizar os modelos de análise da ação coletiva predominantes nas Ciências Sociais usando elementos que resgata da sociologia pragmática francesa. 0 autor propõe uma análise da gramática dos "regimes de ação coletiva", abordagem que, para ele, possibilita a preocupação 
sobre como os sujeitos se mobilizam e a percepção da multiplicidade de motivações que levam ao engajamento político que estaria ausente nas teorias dos processos políticos (Cefaï, 2009, p. 25).

Ademais, Cefaï adverte que a percepção/compreensão "não se exerce em atitudes e opiniões que os atores operariam em seu foro interior, mas em justificações, em releituras ou em anúncios que organizam a experiência", e "reordenam a interação" através dos atos de "enunciação em público" (Cefaï, 2009, p. 29).

Para o autor, a dinâmica de enquadramento e justificação também possibilita, junto com o processo de organização da experiência e da percepção dos sujeitos, a construção de espaços de ação coletiva - arenas - e a constituição de problemas públicos, cujas fronteiras são fixadas e deslocadas a todo tempo por esforços de engajamento, sensibilização, mobilização, propagação etc., e não apenas por estruturas de oportunidades políticas (Cefaï, 2009, p. 16-17). De acordo com ele, "a constituição de um desafio de mobilização, de protesto e de conflito acompanha a articulação de uma arena pública” (Cefaï, 2009, p. 27).

A noção de público, no autor, está ligada a múltiplas possibilidades, que se definem pela ação dos sujeitos no espaço público. Para ele, no bojo do processo de construção de questões públicas, os sujeitos também se autoconstituem, para si e para o público. A noção representa uma tentativa de dar conta das múltiplas dimensões da ação coletiva, pois, ao mesmo tempo que contribui para a emergência, visibilidade e reconhecimento dos sujeitos no espaço público, também está ligada à disputa do espaço público e do que se define enquanto público pelos mesmos sujeitos.

A teoria das arenas públicas, desenvolvida por Cefaï, será referência para entender, sobretudo, a segunda fase do confronto, quando este assume dimensões para além dos locais do conflito.

Na primeira fase, no entanto, como os mecanismos de publicização eram muito incipientes e não acompanharam o processo de constituição da luta, esta foi se dando, prioritariamente, no cotidiano de disputa pelo acesso aos recursos naturais nos locais do conflito. Para entendê-la, buscou-se fazer, com inspiração no método de Thompson (1987), uma análise minuciosa das relações sociais estabelecidas entre os sujeitos envolvidos no conflito e explorar os microespaços e microprocessos a partir dos quais a resistência foi sendo construída. Ademais, com base na ideia goffmaniana de que os enquadramentos (ou frames) são estruturas que orientam a percepção da realidade e a ação dos sujeitos sobre ela (Mendonça, 2012, p. 189), buscou-se também explorar a forma como a grilagem foi enquadrada pelos moradores das comunidades, e as principais motivações para o engajamento, a partir de um diálogo com a noção de "economia moral" de Thompson (1998).

\section{$2 \quad$ Marcha para o Oeste}

A partir da década de 1970, uma série de intervenções do Estado vão trazer mudanças econômicas e socioculturais significativas para o oeste da Bahia. Num contexto de modernização da agricultura nacional e de integração cada vez maior de novos espaços à lógica de produção capitalista, a região vê-se tomada por "grande mobilização de capitais, estimulada pelos incentivos fiscais, pelo baixo preço e elevada disponibilidade de terras na região, e pela indefinição fundiária que a caracterizava" (Comerford \& Kraychete, 1991, pp. 30-31). Programas estatais como o Programa Nacional de Desenvolvimento do Cerrado (PRODECER); Programas de Reflorestamento e Pro-álcool, Programas de Irrigação, e de incentivo à pecuária, foram de suma importância para estimular o processo de expansão capitalista na região (Oliveira, 1983).

A perspectiva era de estimular o aumento da produção de excedentes comercializáveis na região a partir do incentivo à modernização agrícola, com racionalização das relações e das técnicas de produção (através do uso de insumos agrícolas e maquinaria).

Além dos incentivos à modernização agrícola através de créditos e subsídios, há também os investimentos do Estado em infraestrutura que impactaram diretamente a região, com a construção de estradas e rodovias, como a BR 242. ${ }^{3}$ Foram ações fundamentais para

3 A BR 242 é uma rodovia transversal que se estende da localidade
de São Roque do Paraguaçu, no município de Maragogipe, Bahia,
até ao município de Sorriso, no Mato Grosso. A rodovia, principal via 
diminuir o tempo de escoamento da produção no Oeste e para garantir a integração da região com o Brasil Central e especialmente com Brasília, recém fundada.

Junto com as novas estradas, novos povoados surgem, adensando a ocupação de áreas fora do curso dos rios, tais como as áreas de planalto conhecidas como Gerais, onde se desenvolveu historicamente a cultura de criação do gado solto. Tais transformações alteraram significativamente a paisagem do proces so de ocupação, até então marcada por grandes extensões de terra com ocupação rarefeita, e pequenos povoamentos no curso do rio São Francisco e de seus principais afluentes (Comeford \& Kraychete, 1991).

Como consequência, verificou-se um processo de valorização das terras do Oeste baiano, a emergência de sucessivos conflitos envolvendo posseiros e os novos agentes e a introdução de novas relações de trabalho baseadas no assalariamento.

De acordo com Oliveira (1983), o processo de valorização das terras da região se deu com tanta intensidade, que sua mobilização "como meio de produção não utilizado produtivamente" era, muitas vezes, mais lucrativa do que sua utilização produtiva (Oliveira, 1983, p. 34). Foi o que ocorreu com muitas terras financiadas pelo Proálcool. De acordo com o autor, "até junho de 1982 ainda não havia nenhum projeto em funcionamento no Oeste a despeito da existência de 15 destilarias em estágio de implantação".

Não obstante alguns projetos nunca terem sido executados, ainda que tenham se apropriado, de modo fraudulento, do financiamento público/privado, eles tiveram implicações na dinâmica de apropriação fundiária da região. Seja nos casos em que a intenção na obtenção de créditos para compra de terras era apenas especulativa, seja nos casos em que era produtiva, ou ainda quando as duas possibilidades convergiam, o fato é que o processo de valorização das terras do Oeste da Bahia alimentou uma onda crescente de grilagem de terras.

\section{A Invasão dos Gerais}

No bojo dessas transformações a zona rural de Santa Maria da Vitória passou a presenciar a chegada de uma série de novos sujeitos, em especial produtores rurais vindos do sul do Brasil, fazendeiros de Pernambuco e do sul da Bahia e empresas de reflorestamento.

Nesse contexto, o casal de advogados\fazendeiros Paulo de Oliveira Santos e Maria do Socorro Sobral, de Pernambuco, instalou-se, a partir de 1980, na porção oeste do município, zona de planalto marcada pela presença de extensas áreas de mata nativa do cerrado, conhecidas como "gerais". Movidos pela lógica da "terra de negócio" (Martins, 1980), o casal passou a se apropriar, paulatinamente, das terras ocupadas por dezenas de comunidades camponesas e, através da grilagem e da imposição de restrições de acesso e uso a várias áreas, foram formando o que passaram a denominar Fazenda Quatis e Fazenda Cabeceira dos Bois do Mutum. O processo começou com uma apropriação indébita e com algumas compras de pequenas posses de terra em diferentes localidades da região, passou pela falsificação de documentos no cartório de Santa Maria da Vitória, e se estendeu conjugando estratégias de aproximação com algumas famílias e de violência contra as demais.

Figura 01: Interior dos Gerais. Vista de uma das estradas que corta a área. SMV-BA. Oliveira, M. S. (Jan/2014)

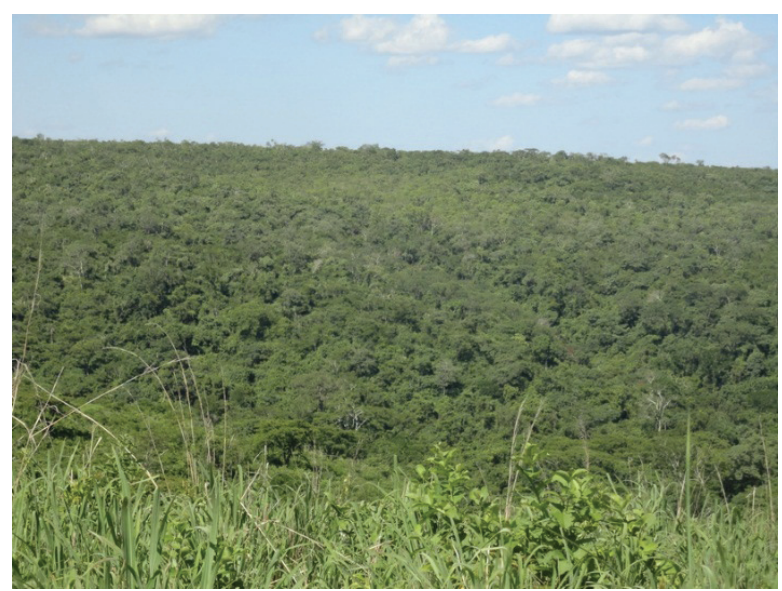


Figura 02: Vista dos Gerais. Santa Maria da Vitória, BA. Oliveira, M. S. (ago/2013)

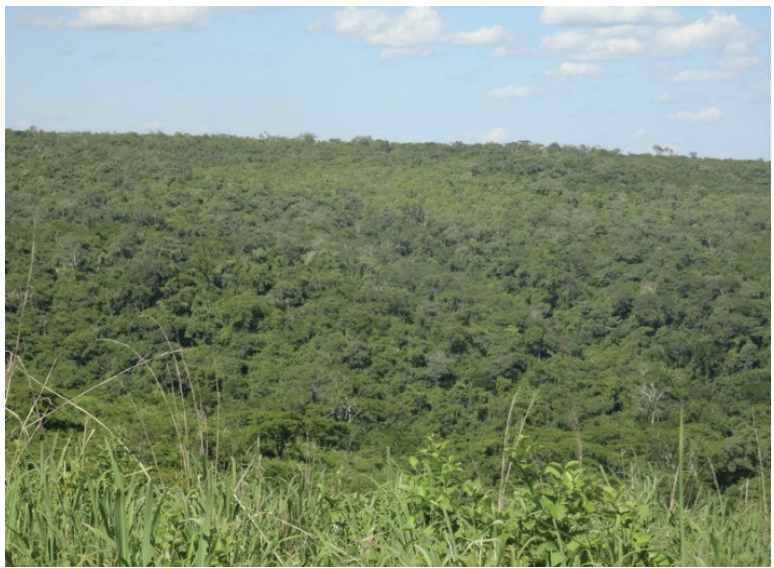

Ao se instalar na região, o casal encontrou uma situação fundiária significativamente complexa, em face da grande presença de terras devolutas e da imprecisão das fronteiras entre estas e as terras que eventualmente tenham adquirido o status de propriedade privada, e com uma lógica de apropriação territorial fortemente consolidada nos costumes locais a partir da articulação entre áreas de uso familiar (usadas para moradia e agricultura) e áreas de uso comum (usadas para a criação do gado solto e para extrativismo) nominadas de "áreas de solta", ou de "fecho" e "fundo de pasto", as quais passaram a ser o alvo prioritário da ação dos grileiros. Tal lógica de articulação do uso familiar com uso comum era a base da reprodução material e sociocultural de dezenas de comunidades rurais situadas na porção oeste do município de Santa Maria da Vitória, desde a segunda metade do século XIX. Dentre essas comunidades, estão Brejinho dos Gerais, Porco Branco, Olho D 'Água do Barro, Pedra Preta, Curral Velho, Salobro, Pajeú, Quati, Jatobá, Vieira, Olho D’Água dos Nere e Mutum situadas no que podemos chamar de primeiro eixo do conflito, e Jacurutu, situada no segundo eixo do conflito. As primeiras começam a sofrer com a ação da grilagem logo no início da década de 1980 e a última passou a vivenciar o problema mais diretamente a partir de 2005, em consequência do avanço da ação dos grileiros.

As áreas de uso comum compartilhadas por essas comunidades foram se consolidando, ao longo do século XX, sem fronteiras definidas. Compreendiam todas as áreas de mata nativa do cerrado não apropriadas como terra de moradia e agricultura por alguma família. Formavam um enorme contínuo rodeado por dezenas de comunidades. A partir da década de 1980, com a chegada de novos sujeitos que não se integraram ao sistema de uso comum e com a formação de pequenas e médias ocupações parcelares (imóveis rurais) em seu interior, esse contínuo foi sendo fracionado em duas grandes áreas de uso comum: uma compartilhada pelas comunidades situadas no primeiro eixo do conflito e outra usada pela comunidade de Jacurutu.

A primeira área apropriada por Paulo Santos e Socorro Sobral foi na localidade de Brejinho dos Gerais, em 1980. Segundo relato dos moradores, colhido pela CDA (2010), os herdeiros de Inocêncio Moreira de Souza passaram uma procuração para o advogado, na perspectiva de ajuizarem uma ação judicial de inventário dos bens deixados pelo falecido e, de posse da procuração, Paulo Santos se apropriou indebitamente das terras objeto da herança (de tamanho indefinido). Em seguida (ainda em 1980), o fazendeiro comprou uma área de 25 ha em Mutum e, ao longo das décadas de 1980, 1990 e anos 2000, comprou outras posses em Salobro (60 ha entre 1985/1986 e 907 ha em data não definida), Mutum (uma de 8 ha e outra de tamanho indefinido, em 1990, e outras duas de 15 ha e 3 ha, em data não definida) e em Jacurutu (8 ha e 2 ha em 2005) (CDA, 2010). Em algumas localidades, a compra das posses foi viabilizada pela intermediação de um morador do local, que passou a ocupar um lugar chave no processo de negociação/ convencimento dos moradores para a venda de pedaços de terras para a família Sobral.

Figura 03: Placa erguida pelo fazendeiro em frente aos Gerais. Na residência aos fundos, passaram a residir os pistoleiros. SMV- BA. Oliveira,.M.S. (ago/2013)

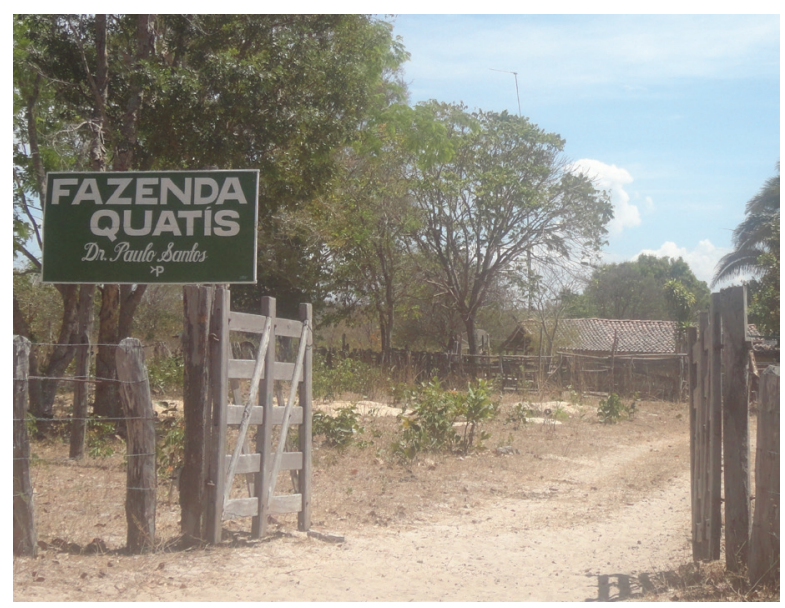


No entanto, se no início tais negociações foram frequentes, logo depois passaram a prevalecer as estratégias de intimidação, violência e expulsão das famílias. Isso se intensifica quando o fazendeiro contrata funcionários armados para garantir o controle das terras, os quais passaram a residir na localidade de Mutum. Nesse sentido, foram marcantes as tentativas de intimidação via destruição das roças dos moradores desta localidade. Segundo os relatos, Paulo passou a criar animais de pequeno porte na proximidade das lavouras e, com isso, inviabilizava a produção de alimentos das famílias. Além do comprometimento das condições de sobrevivência, as famílias de Mutum passaram a receber com frequência ameaças de morte e muitas foram expulsas da terra.

A área de uso comum foi um dos alvos privilegiados da ação do fazendeiro. Com a fixação de funcionários armados na área, passou a cercear o acesso das famílias aos gerais, proibindo a retirada de lenha, frutas e a soltura do gado. Com medo das ameaças, algumas famílias deixaram de usar a área. Isso trouxe impactos significativos para a tradição de criar o gado solto. Algumas famílias tiveram que desistir de criar os animais, e outras - que tinham área suficiente para manter mangas e que puderam investir na lavoura de capim, ou na produção de capim de ração - passaram a manter o gado confinado durante o ano inteiro.

Mas muitos insistiam em soltar, e com isso, conviviam com intimidações frequentes dos jagunços, que ordenavam que o gado fosse retirado da solta, sob pena de perda das rezes. Alguns relatam que muitas vezes tiveram que buscar, contrariados, o gado, ou sofreram prejuízos com perda de animais.

Além do uso de ameaças, o fazendeiro tentava inviabilizar a criação solta nas áreas de uso comum utilizando-se da estratégia de cercamento das fontes de água dos gerais (tais como o brejo de Mutum, o bebedouro do limoeiro e o poço de dentro) indispensáveis para o consumo e sobrevivência do gado criado solto.

A última posse comprada pelo fazendeiro foi na comunidade de Jacurutu, em 2005, equivalente a um quinhão de herança de 08 ha. Foi suficiente para Paulo Santos tentar se apropriar da área dos demais herdeiros (irmãos da vendedora) e, na sequência, de toda a área de solta de Jacurutu.
A estratégia utilizada para a expansão de seu domínio foi um pouco diferente da verificada em Salobro, Mutum e Quati. Nestes locais, o fazendeiro se preocupou inicialmente em fazer amizade com alguns moradores, e em explorar várias possibilidades de negociação. Só depois, começou a conjugar tais ações com o uso da violência física e de frequentes ameaças. Em Jacurutu, os relatos são quase que unânimes em apontar que o fazendeiro já chegou com muita violência. Depois da compra dos 08 ha, Paulo Santos deslocou dois homens armados para residir na casa do falecido, os quais passaram a cercear o acesso e uso dos moradores à área de solta. A partir de então, os moradores de Jacurutu passaram a conviver com agressões, "pirraças", e ameaças e intimidações cotidianas. Além das agressões físicas e psicológicas, os jagunços também provocaram perdas materiais, com o corte das cercas que protegiam as roças na perspectiva de comprometer a subsistência das famílias.

Figura 04: gado solto nos Gerais. Santa Maria da Vitória, BA. Oliveira, M. S. (abril/2013)

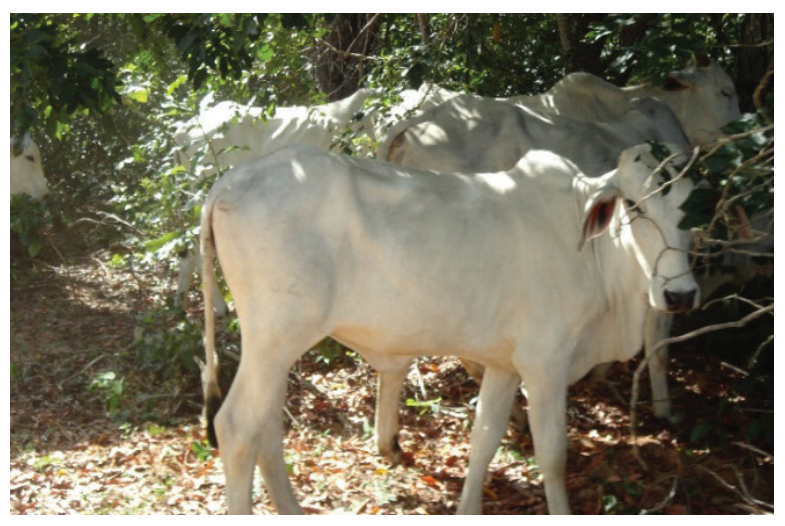

Figura 05: Poço de Dentro. Situado no centro da área comum. É um dos principais bebedouros naturais utilizados para consumo do gado solto. SMV-BA. Oliveira, M. S. (Jan/2014)

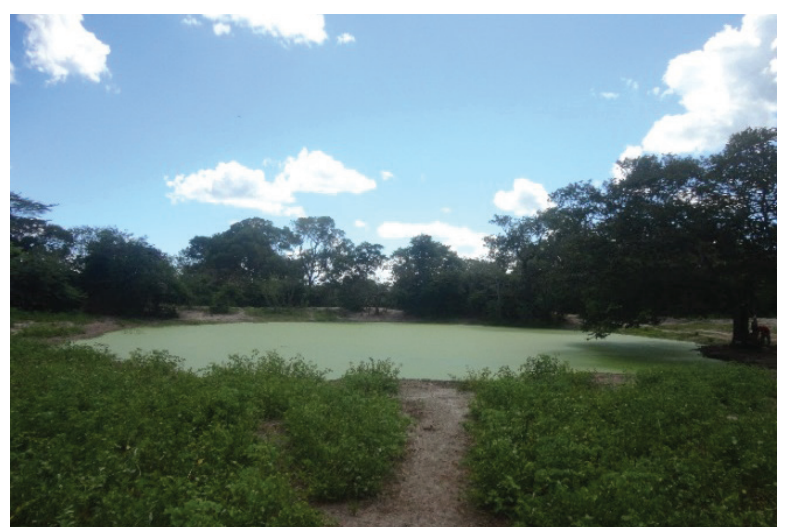




\section{$4 \quad 0$ processo de organização política}

O processo de organização política das comunidades de Salobro, Quatis, Mutum, Jacurutu, Curral Velho, Brejinho dos Gerais etc. contra as ações de Paulo de Oliveira Santos e Maria do Socorro Sobral pode ser compreendido em dois momentos: de 1980 a 2006, e de 2006 até o presente.

Na primeira fase, a luta era travada nas relações cotidianas de conflito, variava em função da maior ou menor resistência de cada família e da relação que cada uma estabelecia com os fazendeiros e seus funcionários, e tinha como marca o caráter predominantemente local. Fora dos locais do conflito, este também chegou a promover repercussões (na imprensa local e junto ao poder executivo estadual desde 1980, e na esfera judicial, na década de 1990). Para tanto, os trabalhadores contaram com o apoio do Sindicato de Trabalhadores Rurais (STR) de Santa Maria da Vitória, da Comissão Pastoral da Terra (CPT) e do Jornal $O$ Posseiro. No entanto, embora tais repercussões tivessem tido impacto na disputa por pedaços de terra entre determinadas famílias e os fazendeiros, não chegaram a produzir desdobramentos no processo de organização política dos grupos para enfrentamento conjunto do problema. Nesse período, a situação era enquadrada como um conflito possessório entre determinadas famílias de lavradores e posseiros e o fazendeiro, que vinha tentando se apropriar de áreas ocupadas por aqueles através de atos de intimidação e grilagem. Tal compreensão era expressão do trabatho realizado pelos mediadores e era influenciada pelos enquadramentos jurídicos disponíveis naquele contexto para defender o direito dos trabalhadores à permanência na terra. Porém, não se tinha a dimensão do alcance do processo de grilagem e da quantidade de comunidades atingidas, e o modo de vida particular dessas comunidades baseado na articulação entre áreas de uso famílias e áreas de uso comum não era visibilizado - nem na esfera judicial, nem nas notícias que circularam na imprensa local.

A partir de 2006, no entanto, o conflito começa a assumir nova configuração. É quando as famílias situadas nos dois eixos de resistência (Jacurutu de um lado, e Salobro, Mutum, Quati etc., de outro) passam a se articular na luta de enfrentamento à grilagem e construir e se inserir em sucessivos e novos espaços.
Tais espaços podem ser divididos entre aqueles voltados à articulação e organização política dos grupos e aqueles voltados para a publicização, denúncia, negociação e encaminhamento de reivindicações. No primeiro grupo, estão as diversas reuniões realizadas nas comunidades atingidas pela grilagem; o Seminário Municipal de Fundos e Fechos de Pasto realizado em Santa Maria da Vitória; os Encontros e Seminários regionais e estaduais dos Fundos e Fechos de Pasto que contaram com a participação de membros destas comunidades, e as visitas e reuniões realizadas em outras comunidades de fundo e fecho de pasto. No segundo grupo, cabe destacar a Audiência Pública realizada em Santa Maria da Vitória, as diversas reuniões realizadas com o poder público (sobretudo - CDA/SEAGRI e Ouvidoria Agrária Nacional/MDA) em Santa Maria da Vitória e em Salvador, a manifestação do dia 15 de abril de 2010 realizada nas ruas da cidade de Santa Maria da Vitória, a repercussão do conflito na mídia, os atos realizados nos processos judiciais (audiências, perícia etc.) e administrativos (o trabalho de campo dos técnicos do CDA para instruir a ação discriminatória) e os momentos de tomada de depoimentos nas delegacias.

Nesses espaços, entrecruzaram-se diversos sujeitos. Merece destaque o papel desempenhado pelo STR de Santa Maria da Vitória e pela CPT, que intensificam o apoio à luta e ao processo de organização política dos grupos e por advogadas/os da AATR, que passam a prestar assistência e assessoria jurídica ao caso. Através da mediação de CPT e STR, as comunidades também começaram a se articular e trocar experiências com outras comunidades de fundo e fecho de pasto e movimentos sociais, a se engajar no Movimento das Comunidades de Fundo e Fecho de Pasto da Bahia, e a estabelecer contato e receber o apoio de outros mediadores. É nesses múltiplos espaços e momentos que se vai constituindo uma arena pública em torno do caso, e o mesmo deixa de envolver interesses apenas das partes em confronto para se configurar como um problema social, envolvendo interesses e responsabilidades do Estado e da sociedade em geral, como será analisado mais à frente.

A seguir, detalha-se todo esse processo de luta desde a década de 1980 até o atual período, dando destaque para a forma como os sujeitos organizaram 
suas experiências de contato com a grilagem, como justificaram suas ações de resistência e enfrentamento e como tal processo se desdobrou na construção de problemas públicos.

\section{$5 \quad$ O desrespeito aos costumes}

O acionamento da noção de direito, a partir da ideia de que "estamos dentro de nossos direitos" assumiu um lugar fundamental no processo de mobilização política do grupo para enfrentamento da grilagem. O reconhecimento dessa condição de sujeitos de direito, presente na maior parte dos depoimentos dos moradores, tanto na região de Salobro como em Jacurutu, advém de uma compreensão do direito ligada aos costumes (conjunto de normas legitimadas pela prática reiterada ao longo da história do grupo) e antecede a mediação legal. É um direito que se produz na vivência cotidiana dos sujeitos sociais, na relação historicamente construída entre eles e na relação que estes desenvolveram com o uso dos recursos naturais. É fruto, portanto, não do imperativo de um "dever ser" abstrato e distante da realidade cotidiana, mas das condições de existência concreta desses grupos sociais - do "ser/sendo" desses sujeitos.

Esse direito costumeiro não foi produzido sem algum contato com a normatividade oficial do direito moderno. A legitimação das formas de acesso à terra através da compra, doação e herança, e até mesmo da posse, evidenciam interações no processo de produção dessas normatividades. No entanto, passaram por processos de legitimação interna e imbricação/ articulação com regras específicas. É o caso do "direito à frente", que possibilita a todos os moradores nas comunidades estudadas o uso das áreas livres para criação de animais soltos e extrativismo. São as áreas geralmente na frente das residências, daí o rótulo.

Nessa perspectiva, percebe-se que havia uma significativa clareza, por parte de muitos moradores de Salobro, Quati e Mutum, de que a nova situação (imposta pela chegada da grilagem a partir de 1980) representava uma ameaça ao modo de vida do grupo, o qual vinha sendo preservado pela existência de um relativo consenso em torno de normas que regulavam as formas de acesso e uso dos recursos naturais no local. Tal ameaça era resultado da lógica de ação dos fazendeiros - Paulo de Oliveira Santos e Maria do Socorro Sobral - que não respeitava os costumes preexistentes. Este parece ter sido o ponto de partida fundamental para a mobilização interna dos grupos no enfrentamento à grilagem a partir de década de 1980 .

Importa destacar que a família Santos/Sobral não foi a primeira "de fora" a chegar àquelas comunidades. O fenômeno da migração não é novo no lugar e fez parte do próprio processo de constituição das comunidades situadas na região de Salobro (primeiro eixo de resistência ao conflito). Após a fixação dos mais antigos, no século XIX, várias outras famílias chegaram ao longo do século XX, vindas, sobretudo, de Macaúbas, Santana, Canápolis e de outras localidades do município de Santa Maria da Vitória. Porém, a partir da década de 1970, começa a se verificar alguns migrantes de outros estados. É o caso dos “Gaúchos”, e da família Sobral, de Pernambuco.

No início, os chegantes eram vistos como "de fora", mas, ao longo do tempo, à medida que se fortaleciam os laços de convivência nos espaços compartilhados e através das relações de parentesco, compadrio e ajuda mútua, muitos foram sendo reconhecidos como "do lugar". No entanto, a incorporação de novas famílias "no lugar" sem maiores conflitos, estava condicionada tacitamente ao respeito às normas costumeiras preexistentes que regulavam as formas de uso e acesso à terra. Nesse sentido, respeitar os direitos preestabelecidos significava adquirir as áreas de uso familiar pelos meios legitimados pelo grupo (compra, recebimento em doação, herança ou posse direta em áreas consensuadas como vagas) e se abster de ações que pudessem cercear o acesso e/ou mudar a destinação das áreas de uso comum. Os chegantes obviamente não eram obrigados a usar a área de uso comum, mas tinham o direito de fazê-lo, se assim quisessem.

A incorporação das "novas" famílias ao sistema de uso comum não se deu de forma uniforme. Ao que parece, a maior parte das famílias se incorporou, mas algumas ficaram restritas à área de uso familiar e passaram a criar o gado confinado na manga o ano inteiro. Foi o caso de algumas famílias de Pajeú e dos gaúchos. Segundo os entrevistados, a convivência com estas últimas sempre foi tranquila, pois eles respeitaram os direitos preexistentes. 
Porém, com Paulo de Oliveira Santos, os relatos apontam que a convivência foi e continua sendo marcada por conflitos. Embora o fazendeiro esteja no local há mais de 30 anos, até hoje ele é visto como um "de fora" por muitas famílias, pelo tipo de relação que foi estabelecida entre o fazendeiro e a maior parte dos moradores do lugar e, sobretudo, pelos conflitos gerados entre a lógica de apropriação territorial do fazendeiro e a lógica de ocupação tradicional do grupo. A relação do fazendeiro com a maior parte dos moradores do lugar é marcada por certo distanciamento, pois além de não morar no imóvel que considera como sede da fazenda que alega possuir, quando passava pelo mesmo estabelecia contatos pessoais com poucas famílias. Muitas sabiam que ele estava na região por ouvir falar, mas nunca o viram de perto. Ademais, as ações do fazendeiro entravam claramente em conflito com a lógica de reprodução social do grupo, pois, enquanto as ações dos moradores estavam orientadas para garantir e preservar as formas de acesso e uso construídas historicamente pelo grupo e consolidadas através do costume, as ações de Paulo Santos estavam orientadas para exercer um controle exclusivo (seu) sobre as terras. Isso significava suplantar as normas preexistentes e se investir do poder de fixar as condições de acesso e uso dos recursos naturais e as pessoas que poderiam fazê-lo. No final das contas, era a disputa pelo poder de dizer o direito no cotidiano daquelas relações que estava em jogo.

Havia certa clareza também, por parte dos moradores de Salobro e comunidades vizinhas, de que as estratégias utilizadas pelo fazendeiro - mais notadamente o uso da violência privada e a falsificação de documentos - significavam uma afronta à lei estatal. No entanto, foi, sobretudo, em torno da ideia de que a grilagem representava uma violação aos costumes locais, e com isso, ameaçava a reprodução do modo de vida do grupo, que a resistência foi iniciada.

Isso dá indicações para se reconhecer que havia, nas comunidades estudadas, uma "consciência costumeira" (Thompson, 1998) significativamente forte que pode ser atribuída à existência de um consenso em torno de "práticas legítimas e ilegítimas" e "normas e obrigações sociais", o que Thompson (1998) vai nominar de "economia moral".
A expressão "economia moral" aparece pela vez primeira em 1971, num ensaio publicado por Thompson, fruto de um projeto de pesquisa desenvolvido pelo autor em parceria com Richard Cobb sobre um conjunto de protestos sociais realizados na Inglaterra e França na década de 1790 (que ficaram conhecidos como "motins da fome"), num contexto de crise econômica e escassez de alimentos nos países. No ensaio, Thompson analisou o padrão de protesto social das ações realizadas na Inglaterra, e verificou que elas derivavam de um consenso de que, em tempos de escassez, os preços deveriam ser regulados para garantir o bem estar público. Tal concepção estava tão arraigada que as tentativas (dos fazendeiros e comerciantes) de se lucrar com a situação de desabastecimento mobilizavam emoções e indignações populares profundas, conferindo um peso moral particular aos protestos.

Os motins da fome na Inglaterra do século XVIII era uma forma altamente complexa de ação popular direta, disciplinada e com objetivos claros [...] é certamente verdade que os motins eram provocados pelo aumento dos preços, por maus procedimentos dos comerciantes ou pela fome. Mas essas queixas operavam dentro de um consenso popular a respeito do que eram práticas legítimas e ilegítimas na atividade do mercado, dos moleiros, dos que faziam pão, etc. Isso, por sua vez, tinha como fundamento uma visão consistente tradicional das normas e obrigações sociais, das funções econômicas peculiares a vários grupos na comunidade, as quais, consideradas em conjunto, podemos dizer que constituem a economia moral dos pobres. 0 desrespeito a esses pressupostos morais, tanto quanto a privação real, era o motivo habitual para a ação direta (Thompson, 1998, p. 152)

A questão não é apenas que seja conveniente reunir num termo comum o feixe identificável de crenças, usos e formas associadas com a venda de alimentos em tempos de escassez, mas também que as profundas emoções despertadas pelo desabastecimento, as reivindicações populares junto às autoridades nessas crises e a afronta provocada por alguém querer lucrar em situações de emergência que ameaçam a vida, conferem um peso moral 
particular ao protesto. Tudo isso, considerado em conjunto, é o que entendo por economia moral. (Thompson, 1998, p. 257).

Embora os contextos sejam bem diferentes, e o próprio Thompson (1998) tenha advertido para os riscos do transplante da categoria economia moral para outros contextos, e da ampliação de seu uso, a realidade objeto de nosso estudo nos dá elementos suficientes para considerarmos pertinente o empréstimo da categoria thompsoniana nas análises aqui realizadas.

Verificou-se que, em Salobro e em algumas comunidades vizinhas, existia uma compreensão muito clara das normas que regulavam as formas de acesso e uso dos recursos naturais no local e tais normas também estavam enraizadas o suficiente para provocar sentimentos de indignação e revolta em casos de desrespeito a elas. Daí o peso moral que as ações do casal de fazendeiro e seus funcionários passaram a assumir dentro dessas comunidades:

Chegaram a medir aqui, na frente de casa. Eu cheguei a dizer para eles. Gente, isso que é uma falta de respeito! A frente das casas da gente? Tem os donos. Os donos estão vivos. (Informante 26 - moradora de Salobro - 30/08/2013).

De primeira tinha respeito. Mesmo se por acaso fo se deles, para fazer o serviço que eles estavam fazendo tinham que falar com o dono. Se podia fazer. De primeira era assim. E hoje, quando eles entrou aí, Deus da terra e do céu são eles. (Informante 26 - moradora de Salobro - 30/08/2013)

Eu acho que ele deveria considerar e fazer igual nós. Eu comprei esse pedacinho, eu vou fazer igual os moradores daqui. Às vezes, quando soltar o gado ai, eu também solto. Não é assim? Fazer desse mesmo jeitinho. No dia que ele soltasse, nos soltava. Não tinha confusão, não. Mas ele comprou um pedacinho lá, comprou um outro aqui, comprou um outro, e quer barrar todo mundo... E nós, quer dizer que nós não tem direito de nada? Tem que ficar embaixo do pé? (Informante 27 - liderança de Quati - 31/08/2013)

Esse sentimento de indignação, presente na maior parte dos depoimentos, demonstra o quanto o conflito transpõe os limites da disputa pelo acesso a bens materiais, e assume significativos muito mais amplos para os moradores do lugar.

A recusa em "ficar em baixo do pé" do fazendeiro, na citação acima, indica que muitas outras questões estão em jogo. Lutam não somente pelo acesso e uso dos recursos naturais, mas, sobretudo pelo poder de gerir autonomamente suas vidas - de preservar a liberdade e tranquilidade que desfrutavam antes da chegada da família Sobral.

Nós vivia aqui a vida tranquila. Tínhamos-nos aquela liberdade de ir aonde nós quisesse. Para nós estava bom. Hoje em dia pra nós só virou um aperto, porque a gente não tem aquela liberdade que tinha. Como era antes... De sair para colocar uma roça aonde a gente quisesse. Hoje em dia, o direito que a gente tinha a gente não tem mais... Porque vê essas pessoas que chegam, que compram uma gleba pequenininha, e às vezes querem ser dono do mundo todo. Querem ser dono até do direito da gente, porque hoje em dia, no caso, nós não podemos mais quase sair para o lado de fora aí. (Informante 5- liderança de Quati - 31/08/2013)

Porque nós somos filhos de Deus. Somos filhos da terra. Ninguém tá brigando por terra. Porque terra a gente só tem sete palmos. Mas esses sete palmos é dado por Deus, não precisa nós brigar por terra. Nós quer é viver, porque a terra é o seguinte: Deus deixou a terra para a gente sobreviver em cima dela e depois ela mesma comer a gente. Então é isso que a gente quer. Ninguém tá brigando por terra. A gente quer é a liberdade. Aquilo que os avós da gente deixou... os pais da gente...Aquilo que a gente viu... A gente quer que os filhos da gente veja, os netos da gente.... É isso! (Informante 5- liderança de Quati - 31/08/2013)

A liberdade e tranquilidade seriam como um bem imaterial deixado como legado pelos seus antepassados, e que se quer deixar também para as futuras gerações. A terra é vista como um presente de Deus, que, no final das contas, não é de ninguém e nem fica para ninguém. Eles que pertencem à terra e não o contrário. É uma lógica onde se reconhece a simbio- 
se entre a terra e homem. A terra que oferece o alimento e as condições de sobrevivência ao homem é a mesma que o absorve - e dele se alimenta na morte. Deste modo, o que fica é o que foi vivido e como foi vivido, e nesse sentido, a liberdade e a tranquilidade têm valor incomensurável e indisponível - ela é herança do passado e é esperança de vida para o futuro.

Quando a grilagem se estende até Jacurutu, em 2005, a emergência de sentimentos de indignação e revolta nos moradores também está relacionada à existência de uma "consciência costumeira" significativa forte no local. No entanto, nesta comunidade, é o entendimento de que a atuação do fazendeiro representou um "desaforo" e que o mesmo "já chegou botando ordem" e "mexendo com todo mundo" que impulsionou a rápida mobilização do grupo. Tal compreensão, associada aos fortes laços de parentesco, que contribuíam para a existência de relativa coesão no grupo, vão assumir papel fundamental no encorajamento para a luta.

\section{As lógicas de justificação e de legitimação dos direitos}

O processo de caracterização da grilagem como uma situação de desrespeito aos costumes locais, também levou ao exercício crescente de reafirmação das bases de legitimidade do direito costumeiro, que, embora já norteassem a interação entre os moradores do local, eram implícitas. Com a emergência do conflito envolvendo a grilagem de terra, estas bases passam a ser acionadas e explicitadas como mecanismo de justificação de direitos, sendo enunciadas a partir de três principais pilares: a posse direta, a prática reiterada e preexistente, e a relação de pertencimento dos moradores com o lugar.

Se for existir fazenda. No caso de ser fazenda... Fazenda quem tem somos nós. Às vezes a pessoa pode chegar aqui e ver alguma coisa... Que a gente vive aqui, a vida toda né? Se sai, mas ...Vai lá no que é dele para ver se vê alguma coisa que diga assim que tem um tronco, tem um curral... Se tem alguma coisa. Não tem nada disso. Só tem lá é um amparo para chegar e dizer que tá ali para não perder os direitos. Mas nós é que não podemos perder os nossos direitos, porque nós já somos daqui... Nós não vinhemos de lugar nenhum. Nós viemos vindo por Deus, e tamos aqui e daqui nós só sai mesmo se for para o cemitério, porque para outro lugar não tem para aonde nós vai. Para ir para embaixo de ponte? Nós sair daqui, por exemplo, para ir para debaixo de uma ponte, o que a gente vai arranjar lá? Então... Essa coisa desses direitos que a gente tinha, a gente não quer perder ele de jeito nenhum. Não quer porque... Ele que veio de lá de fora, ele vá cassar o jeito dele. Uma pessoa dessas não é gente de comunidade. Aqui é uma comunidade. Nós somos unidos, graças a Deus. A família nossa tá toda aqui criada, graças a Deus. Eu pelo menos posso mostrar da onde eu já mudei minha casa para outro canto. Acho que não tem 20 metros. Tá lá em casa, pode ir lá ver... E ver se a gente é daqui ou se não é. (Informante 5- liderança de Quati - 31/08/2013)

É que ele já chegou aqui e já encontrou a gente, né? Ele tinha que respeitar os direitos da gente. A gente respeita o direito dele. Ele solta o gado dele e nós nunca reclamou. Ele é que queria que nós não soltássemos nenhum gado. E a gente não vai daro direito da gente para ele. Quando ele chegou aqui, a gente já tava. Os avós da gente já foi, os pais da gente já foi. Aqueles mais antigos já foi. E a gente tá aqui. E aqui a gente quer ficar. É aqui que a gente quer criar os filhos da gente. (Informante 5- liderança de Quati - 31/08/2013)

Ele diz que é dele, mas nós não considera que é dele não. É nosso. Nós nascemos e nos criamos aqui" (Informante 11 - liderança de Quati - 31/08/2013)

Ele diz que tem alguma coisa... que tem fazenda aí, mas nós não vemos nem um pé de capim dele aí. (Informante 11 - liderança de Quati - 31/08/2013)

Estas citações acima ajudam a compreender a lógica que orienta os moradores na justificação de seus direitos. Percebe-se que a posse direta aparece como elemento importante de justificação dos direitos. 0 fato do fazendeiro não exercer a posse direta sobre os bens que alega possuir é vista com estranhamento pelo grupo, pois contrasta com a lógica de apropriação territorial tradicional, onde o trabalho concreto tem função elementar. Tal compreensão está em consonância com a noção da "terra de trabalho", cuja 
apropriação se baseia no trabalho familiar e comunitário, em contraste com a de "terra de negócio", apropriada pelo capital para gerar crescentes lucros, com base na especulação e/ou exploração do trabalho alheio (Martins, 1980).

Mas a relação destes grupos sociais com a terra não é marcada apenas pela produção de bens materiais necessários à subsistência (para a qual a posse e o trabalho são condições elementares), mas também por valores e bens imateriais, os quais assumem um lugar fundamental no processo de justificação dos direitos no momento de conflito.

Nessa perspectiva, percebe-se claramente que é na situação de conflito e de ameaça ao modo de vida do grupo que a identidade ser "do lugar" se fortalece e se afirma em oposição ao "de fora", e o sentimento de ser comunidade, como sinônimo de união, aparece. Nesse processo, a antiguidade da ocupação, associada à relação de pertencimento com o lugar é acionada como elemento chave de diferenciação social e de afirmação de direitos, sendo corriqueira a menção de que "nós somos nascidos e criados aqui". Mais do que expressar a antiguidade e preexistência do grupo naquelas localidades, tal frase evidencia que o grupo possui uma história de vida no lugar e ali está enraizado.

Em Jacurutu, a relação de pertencimento com o lugar também aparece de forma forte no processo de justificação e legitimação dos direitos.

Eu acho que o dono é quem nasceu e se criou em cima (Informante 22 - moradora de Jacurutu 05/09/2013)

Por cima de nós ele não podia passar. Quem nasceu e criou aqui, né? (Informante 22 - moradora de Jacurutu - 05/09/2013)

Pra mim o direito é dos morador, né não? Que tem seus pedaços de terra. Porque o da gente a gente não pode dar para os outros e o dos outros também ninguém quer [...] Eu moro aqui. Se chegar um, chegar e disser: a casa é minha. Eu não entrego não. Né? Então eu tenho direito. (Informante 21 - moradora de Jacurutu - 04/09/2013)
A gente nasceu e criou no nosso lugar. A gente não comprou, mas vem de herança toda vida. Posse velha toda vida, dos avôs, dos bisavôs, dos pais. Então a gente tá até hoje. Para chegar outro assim, pra gente entregar e sair fora, aí fica meio pesado. Sem comprar, sem a gente vender e sem ele comprar". (Informante 28 - morador de Jacurutu 05/09/2013) E sem dar, né? (Informante 29 - moradora de Jacurutu - 05/09/2013).

Aqui você sabe, a população daqui do lugar é fraca. Aqui não tem fazendeiro. Mas só que a gente tava em cima dos direitos, a gente tava forte, né? Porque nós em cima dos direitos nossos. No nosso terreiro nós não somos forte? [...] Em cima da terra nossa, né? A gente nasceu e criou aqui, pra ele chegar e invadir assim. Meter a cara mesmo, com cara de pau, eu achei muito pesado. (Informante 14 - morador de Jacurutu - 05/09/2013)

Assim, a anterioridade alegada não é apenas das pessoas naquele lugar, mas também das normas - de um direito preexistente. Nessa perspectiva, a defesa do costume também aparece como elemento chave no processo de justificação e legitimação dos direitos.

Nesse exercício de justificação de direitos, impulsionado pela situação de conflito verifica-se que alguns moradores da região de Salobro fazem questão de destacar que as pequenas glebas que foram compradas pelo fazendeiro são reconhecidas pela comunidade como aquisições legítimas e não estão sendo objeto de questionamento. Assim, a luta é pela preservação dos direitos da comunidade sobre as outras áreas de que Paulo Santos vem tentando se apropriar sem ter adquirido.

Eles dizem aí que é deles. Mas nós não estamos lutando pela terra deles não. Nós estamos correndo atrás do que é nosso. O que é dele.... Nós não fala que ele não tem terra não. Tem essas glebinha aí, que ele comprou. (Informante 11 - liderança de Quati - 31/08/2013)

O que ele comprou deixa, mas a parte que a gente não vendeu, não deu, não emprestou, a gente não abre mão não. A gente não abre mão dos nossos direitos não. Nós precisamos dos nossos direitos (Informante 17 - liderança de Salobro - 29/08/2013) 
A preocupação dos moradores de Salobro e Quati em destacar este aspecto reforça o entendimento sustentado aqui de que é em torno da luta pelo respeito aos costumes locais que a ação coletiva foi sendo construída. Isso implica reconhecer como legítimas as práticas dos fazendeiros que não estejam em desacordo com os costumes - no caso, a compra de pequenas posses de terra. Assim, o enquadramento interpretativo baliza tanto a construção de entendimentos que dão subsídios para justificar o enfrentamento, como também fixa os limites de seu alcance, nos esforços de produção de engajamento e unidade do grupo.

As lógicas de justificação e legitimação dos direitos apresentadas, mesmo que com base apenas nos depoimentos dos moradores das comunidades, já expressam, em certa medida, um exercício construído num contexto de denúncia e publicização do conflito. Tais noções vão ser a base para a constituição do conflito enquanto um problema público, o que vai ocorrendo a partir da incorporação de outras linguagens, que façam sentido não apenas para as comunidades mobilizadas, mas também para o Estado e para a sociedade em geral.

\section{$7 \quad 0$ acionamento do poder judiciário e a lógica de ação dual}

O acionamento do poder judiciário para resolver questões decorrentes dos conflitos de terra é um mecanismo de ação presente na área objeto de estudo desde o final da década de 1970, quando os primeiros casos de grilagem aparecem. Naquela época, ganhou significativa repercussão o litígio envolvendo moradores de Mutum e um fazendeiro apelidado de "Zé Capa Curta". De acordo um morador da região que acompanhou de perto o conflito na condição de delegado sindical, com as ameaças, as famílias decidiram acionar o STR de Santa Maria da Vitória, que passou a apoiá-los. Disponibilizou um advogado para prestar-lhes assessoria e assistência jurídica, o qual interpôs uma ação judicial requerendo a proteção da posse em favor dos moradores de Mutum. Segundo o entrevistado, o litígio culminou num acordo judicial firmado entre a família do fazendeiro e cada uma das famílias de Mutum envolvidas no conflito, o que le- vou ao fracionamento e à individualização da área de solta em disputa. Nas décadas de 1980 e 1990, houve outras ações judiciais envolvendo conflitos de terra nas localidades de Brejinho dos Gerais e Salobro, entre famílias específicas dessas localidades e Paulo de Oliveira Santos.

A partir do momento em que se intensificou o processo de organização política das comunidades de Jacurutu, Salobro, Mutum, Quati e outras para garantir a continuidade do uso da área de solta, a partir de 2005, o acionamento do Poder Judiciário, sobretudo por parte dos trabalhadores, passou a ocorrer de forma ainda mais sistemática. Entre 2005 e 2013 foram abertas várias ações judiciais para discutir questões vinculadas ao conflito entre moradores das comunidades objeto de estudo e os fazendeiros Maria do Socorro Sobral e Paulo de Oliveira Santos. Destas ações, apenas três têm os fazendeiros como autores (as ações de interdito proibitório e a ação reivindicatória). Todas as demais foram propostas pelas/os advogadas/os dos trabalhadores, particulares ou ligadas/os à AATR (ação de preferência cumulada com pedido de perdas e danos, mandado de segurança e habeas corpus), ou pelo Ministério Público do Estado da Bahia (a ação penal e a ação civil pública), ou pela Procuradoria do Estado da Bahia (ação discriminatória judicial), ou pelo CDA/ SEAGRI (Alvará).

Portanto, as/os advogadas/os dos trabalhadores têm acionado os instrumentos de disputa judicial mais do que os fazendeiros. Constatação reforçada porque, mesmo nos casos das ações propostas pelo MPE e PGE, a atuação de advogadas/os dos trabalhadores, dos trabalhadores e das organizações que os apoiam tem sido fundamental para sensibilização e convencimento dos promotores de justiça e procuradores do Estado da pertinência de proposição das ações. A Ação Civil Pública, por exemplo, foi interposta pelo MPE após o mesmo receber representação dos trabalhadores denunciando o cerceamento do poço de dentro por parte dos fazendeiros e requerendo a tomada de providências por parte do órgão. A ação discriminatória judicial, por sua vez, também foi resultado das reivindicações dos trabalhadores perante o poder executivo estadual, em reuniões com o CDA/ SEAGRI e com a Ouvidoria Agrária Nacional, que levou 
à realização da "Ação Discriminatória Administrativa Rural da gleba Jacurutu”, que antecedeu e deu subsídios para a proposição da discriminatória judicial. Já a ação penal, também proposta pelo MPE, foi subsidiada por inquérito aberto com base em boletim de ocorrência registrado pelos fazendeiros, acusando os trabalhadores de desobediência à ordem judicial e de prática de violência contra seus funcionários. Porém, no curso da investigação criminal, verificou-se que os indícios de autoria de atos tipificados como crimes recaiam sobre o filho e funcionários do fazendeiro, o que levou a autoridade policial a indiciá-los, e o ministério público a oferecer a denúncia (através da proposição da Ação penal) contra os mesmos.

Verifica-se que o uso dos instrumentos de disputa judicial tem se dado junto com a utilização de espaços de denúncia e reivindicação extrajudiciais - tais como o acionamento de outras instâncias do Estado (sobretudo o Poder Executivo e o Ministério Público) e não institucionais, como a ação direta. Na verdade, percebe-se um uso relativamente articulado de todos esses mecanismos, gerando influências mútuas (o uso dos mecanismos de ação direta e acionamento do poder executivo e MP podem influenciar significativamente as disputas no plano judicial, da mesma forma que as decisões ou omissões decorrentes dos processos judiciais podem motivar ou inibir o uso dos outros dois mecanismos de ação).

Tal lógica de ação vem sendo conceituada por Cohen e Arato (2000) como lógica de ação dual, de fundamental importância para compreender a especificidade e potencialidade dos movimentos sociais contemporâneos. Tomando como exemplo o movimento feminista e contrapondo-se às teorias etapistas, Cohen e Arato (2000) defendem que a tendência à institucionalização dos movimentos sociais não tem substituído as ações coletivas de massas, nem a política orientada para o fortalecimento da identidade dos grupos. Na verdade, verifica-se um uso alternado das ações de massa e da pressão política, dependendo das oportunidades políticas disponíveis e do tema que se trate (Cohen \& Arato, 2000, p. 617). Os autores defendem ainda que a concepção de atuação dual oferece um critério para se analisar o êxito dos movimentos, a partir da capacidade e habilidade de combinarem ações nessas duas esferas.
Apesar de Cohen e Arato (2000) não se debruçarem sobre as estratégias de ação no plano judicial, a concepção de ação dual ajuda a analisar o lugar da disputa institucional (na qual se inclui a disputa judicial) no repertório de ações das comunidades de fundo e fecho de pasto e de sua rede de apoio.

O uso de mecanismos extrajudiciais está presente nas reivindicações formuladas perante a Coordenação de Desenvolvimento Agrário/SEAGRI-BA, nos abaixo assinados e representações encaminhadas ao Ministério Público do Estado pelos trabalhadores, por suas/seus advogadas/os, pela CPT e pelo STR e nas denúncias encaminhadas à Ouvidoria Agrária Nacional/MDA. A provocação dessas instâncias se dá, em geral, através da mediação do STR, CPT e AATR, mas as reuniões e audiências realizadas com todos esses órgãos contam sempre com a participação de lideranças dos trabalhadores, que falam sobre a realidade vivenciada e encaminham reivindicações de tomada de providências.

As reivindicações perante CDA/SEAGRI visaram a abertura de uma ação discriminatória administrativa para confirmar a existência de terras devolutas na área em litígio, e a regularização fundiária em favor das comunidades de fundo e fecho de pasto que a usam secularmente. 0 requerimento ocorre no bojo do processo de inserção das comunidades de Jacurutu e Salobro no movimento das comunidades de fundo e fecho de pasto da Bahia, onde a pauta da regularização fundiária assume um lugar central.

Foram encaminhados abaixo assinados e representações ao Ministério Público em pelo menos dois momentos: para comunicar e requer a tomada de providências em relação às ameaças perpetradas pelos funcionários do fazendeiro contra os trabalhadores, e em relação ao cerceamento do acesso ao poço de dentro.

Já as denúncias encaminhadas à Ouvidoria Agrária Nacional foram as de ameaças e violências sofridas pelos trabalhadores em consequência da ação dos fazendeiros e seus funcionários, requerendo a intervenção do órgão na mediação do conflito. Foi a partir desta provocação que ocorreu uma Audiência Pública em Santa Maria da Vitória para discutir o conflito. 
A audiência foi realizada no dia 23 de abril de 2009 sob a coordenação da Ouvidoria Agrária Nacional e contou com a participação do juiz de direito da comarca, do Ministério Público, do Prefeito Municipal, do Comando da Polícia Militar na região, da Casa Militar do Governador, do INCRA, CDA, Instituto de Gestão das Águas e Clima (INGÁ-BA), Instituto Brasileiro de Meio Ambiente (IBAMA), do Secretário de Meio Ambiente do município de Cocos, AATR, CPT, STR de Santa Maria da Vitória e Correntina, Coordenação dos Acampados, Assentados e Quilombolas (CETA) e de lideranças das comunidades rurais envolvidas no conflito. A experiência abriu as portas para a realização de uma segunda audiência dessa natureza para discutir outros conflitos agrários da região, realizada no município de Correntina e também sob a coordenação da Ouvidoria Agrária Nacional.

O uso do mecanismo da ação direta, por sua vez, dá-se em, pelo menos, três episódios. Frustrados com a demora da autoridade policial em visitar o local do conflito para confirmar a denúncia do fechamento do poço de dentro, moradores de Salobro, Mutum, Quati, Pedra Preta e outras localidades se reuniram e formaram um grupo de cerca de 60 vaqueiros para retirarem a cerca. De acordo com os relatos, quando o grupo chegou ao local, dois funcionários do fazendeiro estavam de plantão no local, armados, mas quando viram o volume do grupo, fugiram e não ofereceram resistência à liberação do acesso ao poço. Outro episódio aconteceu em Jacurutu, quando os funcionários do fazendeiro come- çaram a cortar as cercas que protegiam as roças das famílias. A ação, apesar de ter causado muitos prejuízos para os moradores da comunidade, conseguiu ser interrompida por um grupo de cerca de 15 trabalhadores. Mas o caso mais emblemático foi, sem dúvida, a manifestação realizada na cidade de Santa Maria da Vitória, em abril de 2010, reunindo cerca de 1500 pessoas (entre trabalhadores rurais da região, moradores da cidade e representantes de organizações de apoio), em um "Ato de Desagravo" à prisão de João Cerrano Sodré, presidente do STR de Santa Maria da Vitória e de Marilene de Jesus Cardoso Matos, agente da CPT, por determinação do então juiz do Juizado Especial Cível da Comarca de Santa Maria da Vitória, Eduardo Pedro Nostrani Simão. A prisão foi determinada com o argumento de que os sujeitos praticaram crime de "coação no curso do processo", por terem encaminhado ofícios à Ouvidoria Agrária Nacional e à Corregedoria do Tribunal de Justiça (TJ) da BA, relatando o conflito e solicitando a adoção de medidas judiciais e extrajudiciais cabíveis para garantir os direitos dos agricultores familiares da região, que estavam com suas vidas ameaçadas pelo cumprimento de decisões judiciais proferidas pelo referido juiz.

A manifestação circulou pelas principais ruas da cidade, com paradas em locais simbólicos para a luta dos trabalhadores rurais da região - o local onde foi assassinado o advogado Eugênio Lyra, em 1977, a porta do Fórum (figura 31), dentre outros locais.

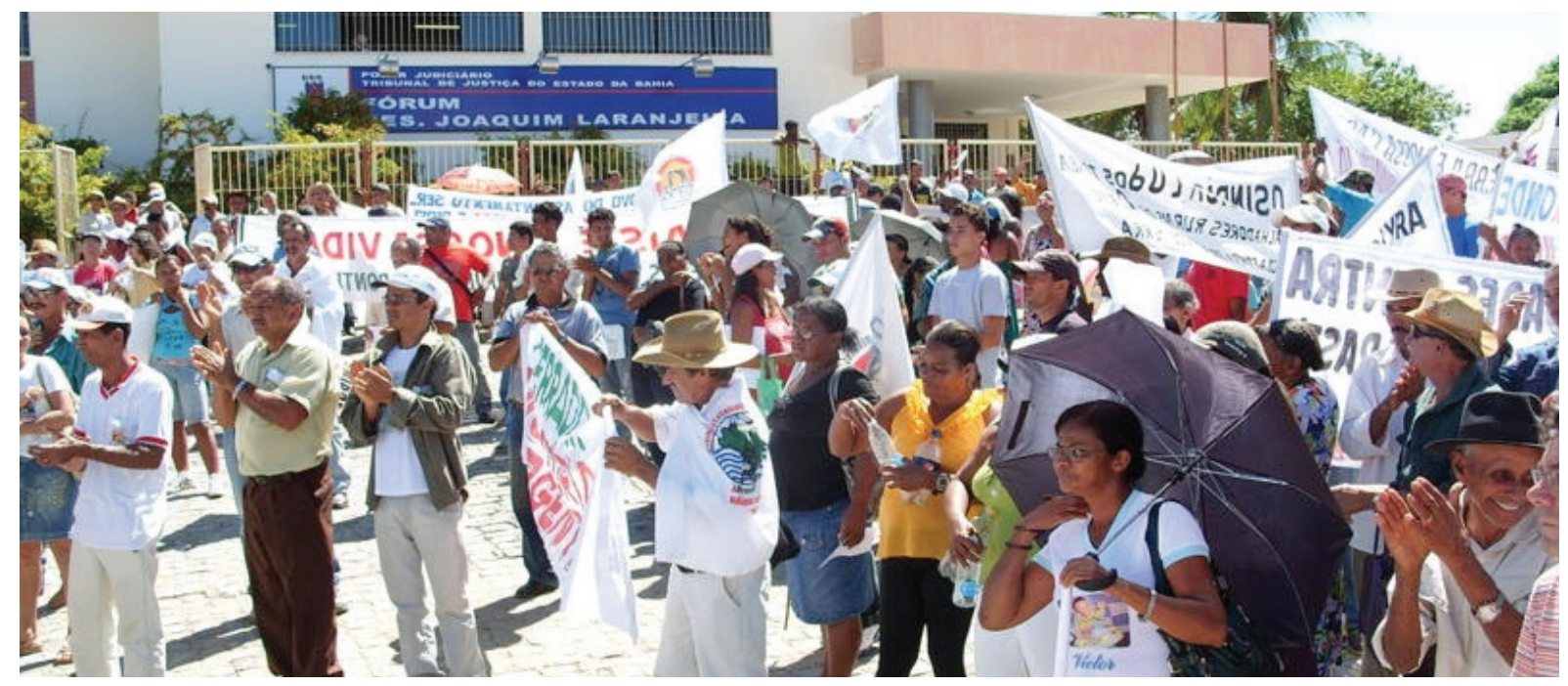


$\mathrm{O}$ ato teve grande repercussão no processo judicial de onde emanaram as decisões objeto de questionamento, levando o juiz a se reconhecer suspeito para continuar atuando na lide. Com isso, o processo foi remetido para o juiz substituto da comarca, que decidiu pelo deslocamento da competência de julgamento da ação para a justiça comum. Abaixo, segue um trecho da versão do próprio juiz do juizado sobre os fatos:

Sujeitos que nem fazem parte do processo representaram este magistrado na Corregedoria pedindo providências judiciais e extrajudiciais - como se tivessem procuração das partes e fossem formados em Direito com registro devido na Ordem dos Advogados do Brasil. Sem contar que do fato resultou o crime de coação no curso do processo, crime contra a jurisdição, portanto. Além de denunciação caluniosa (art. 339 do CP) e crime contra a honra. O fato é que determinei a abertura de inquérito e decretei a prisão preventiva dos agentes coatores, sendo que estes conseguiram liberação por meio de habeas corpus já no dia seguinte. Após tal fato, na minha ausência, houve passeata na qual membros chamaram este magistrado de forasteiro e de nazista. Disseram que este magistrado era de Santa Catarina e para lá deveria voltar. Hoje recebi ofício endereçado pelo Desembargados Gercino José da Silva Filho, na qualidade de ouvidor Agrário Nacional, solicitando a remessa do processo $n^{\circ} 00211 / 08$ para a instância ordinária, sob a alegação de que se trata de ação possessória envolvendo conflito agrário de caráter coletivo e que o valor da causa é superior ao teto estabelecido para os procedimentos do juizado. (TJ-BA, Ação de Interdito Proibitório $n^{\circ}$ JPCSM-TAM 00211/08, fls 174/174)

Na visão do referido magistrado, a lógica de ação dual seria um desrespeito à instituição do Judiciário. Sua declaração é reveladora de como o distanciamento do Poder Judiciário brasileiro da realidade dos movimentos sociais e de suas estratégias de ação pode levar à criminalização de ações legítimas e democráticas de participação e pressão popular. Ademais, revela uma concepção de um Poder Judiciário encastelado em seu campo, avesso ao controle popular e fora do mundo da política (não podendo, inclusive, se contaminar por ele), só podendo ser questionado dentro de seu próprio campo e pelos profissionais autorizados a atuarem no mesmo.

Não é cabível refutar ação em trâmite no Juizado por influência política, pressões de toda ordem e omissão na defesa dos direitos em juízo. Note-se que em nenhum momento foi impetrado mandado de segurança na turma recursal para discutir a competência - procedimento que seria padrão, correto e honesto. Em nenhum momento foi aforada suspeição contra este magistrado. o que foi feito foi jogar o nome deste magistrado e de sua família na mais suja lama, repito. É o jogo de não tomar a medida adequada para não correr o risco de o órgão judiciário superior dizer que o juiz tem razão. Preferem não utilizar as medidas jurídicas que o direito coloca a disposição. Preferem fazer jugo político. Preferem fazer graça com o exercício da atividade jurisdicional. Não é crível que o sobrenome do avô deste magistrado seja utilizado pela escória da política local para angariar votos de analfabetos. No caso concreto, só me resta declarar-me suspeito, não por motivo de foro íntimo, mas em razão dos motivos supramencionados. Acresço que não posso ser massacrado por bandidos que nem fazem parte do processo, ainda que tais marginais tenham articulações políticas fortes e consigam tudo o que querem. Podem comprar o vendido jornalesco de Salvador, desvirtuar os termos do processo (inclusive no que tange a res in judicium deducta), podem utilizar de força política, repudiar a minha origem, dizer que eu sou Nazista e conseguir suprimir a justa pena, mas não vão conseguir me causar medo, talvez apenas pena - que é um sentimento menor, mas inevitável. (grifo do juiz) (TJ-BA, Ação de Interdito Proibitório n JPCSM-TAM 00211/08, fls 176)

Esse entendimento também é reproduzido pelos fazendeiros, ao se pronunciarem no processo após a manifestação de rua:

Manipulados, os réus, por várias vezes pressionaram, coagiram a justiça, pelas várias formas, chegando a desmoralizar até a pessoa do magistrado, usando como estratégia de força a coação, o escárnio, a execração pública, tudo para ganhar no grito em detrimento do direito e da razão" (TJ-BA, Ação de Interdito Proibitório n JPCSM-TAM 00211/08, fl 249). 
Importa destacar que, embora o magistrado não tivesse ainda tomado conhecimento, na oportunidade em que proferiu a citada decisão, o acionamento da instância recursal do Juizado Especial foi feita pela advogada dos trabalhadores, através da impetração de Mandado de Segurança. No entanto, o recurso não logrou êxito, haja vista que não há consenso no direito brasileiro sobre o cabimento de recurso para impugnar decisão interlocutória proferida no âmbito dos juizados especiais. Inclusive, foi justamente a impossibilidade de recorrer da decisão judicial, o que configura violação ao princípio constitucional da ampla defesa, um dos motivos que levou o STR e CPT, assessorados pela AATR, a comunicarem à Corregedoria do TJ-BA e Ouvidoria Agrária Nacional a situação do conflito.

Cabe observar também a forma preconceituosa como os trabalhadores rurais aparecem na visão do magistrado - como analfabetos e objetos de manipulação eleitoreira - e do fazendeiro - como objetos de manipulação. São visões onde os trabalhadores aparecem como destituídos de protagonismo político, e incapazes de agir em defesa de seus próprios interesses, já que atuam em consequência da manipulação de outros sujeitos.

\section{O Problema Público}

Os processos de denúncia e a publicização compõem o repertório de ação da maior parte dos movimentos sociais contemporâneos. Com eles, os movimentos buscam sensibilizar a sociedade em geral de uma questão, conquistar o seu apoio e, em alguns casos, a adesão de novos membros. Tais mecanismos são utilizados, muitas vezes, associados a reivindicações por direitos direcionadas ao poder público. É, sobretudo, nos espaços de publicização, denúncia e reivindicação que o conflito aparece de forma mais clara como um problema público. No conflito em estudo, as denúncias à opinião pública foram feitas por cartas abertas, notícias de jornal e manifestações de rua, e as reivindicações formuladas através ofícios, petições, reuniões e audiências para diversas esferas do poder público - notadamente a CDA/SEAGRI (poder executivo estadual), Ouvidoria Agrária Nacional/ MDA (poder executivo federal), o Poder Judiciário e o Ministério Público Estadual.
Através desses espaços, o conflito ganhou visibilidade estadual e passou a integrar o quadro mais amplo de conflitos agrários do atual contexto, envolvendo as comunidades de fecho e fundo de pasto na Bahia e outros grupos camponeses, ameaçados com o avanço da grilagem, do agro e hidronegócio, da mineração e dos grandes projetos financiados pelo Estado. Assim, deixou de ser tratado como uma questão apenas local para ser visto como um problema social, que atinge parcelas cada vez mais significativas dos povos do campo, e traz impactos para a sociedade em geral. Nesse processo, a ameaça de expropriação territorial significa muito mais do que o cerceamento do acesso a um bem material. Significa exterminar a organização social e cultural de comunidades inteiras, que se constituíram historicamente a partir de um modo de vida singular, baseado na articulação entre áreas de uso familiar e áreas de uso comum, conhecidas como soltas ou fecho/fundo de pasto, numa relação de pertencimento com o lugar e de respeito e equilíbrio com o meio ambiente. Desta forma, a luta pela preservação do modo de vida desses grupos é também uma luta pela preservação dos recursos naturais, que vêm sendo devastados pela lógica de exploração capitalista da terra e por um modelo de desenvolvimento social e ambientalmente insustentável, pois baseado na concentração de riquezas, exploração do trabalho alheio, e exaustão dos recursos naturais.

A denúncia da grilagem também aparece com bastante força na repercussão regional e estadual do conflito, figurando em praticamente todas as chamadas de notícias de jornal e também nas cartas abertas formuladas sobre o conflito pelas organizações mediadoras, notadamente após a prática ter sido objeto de análise e confirmação técnica. A confirmação é resultado da realização de um procedimento administrativo de discriminação de terras, realizado pelo CDA/SEAGRI, a requerimento das comunidades envolvidas no conflito e das organizações que as assessoram, e que conclui serem as áreas em litígio terras públicas devolutas, que foram objeto de grilagem pelo fazendeiro a partir da década de 1980. Dessa forma, a denúncia da grilagem também assumiu um lugar importante para que o conflito se caracterizasse enquanto um problema público. Além de se sustentar em condutas moralmente condenadas e 
juridicamente tipificadas como crimes - violência privada e fraude documental, a caracterização da grilagem também põe em questão a condição do fazendeiro como proprietário da área em litígio e, consequentemente, do seu lugar de portador de direitos vinculados a esta condição. Com isso, relega para a ilegalidade todos os atos por ele praticados baseados na defesa da propriedade. O reconhecimento da área como pública também assume um peso importante para a confirmação da existência de interesse público no conflito, trazendo impactos diretos para os processos judiciais que tramitam em relação ao conflito. ${ }^{4}$ No entanto, o reconhecimento da dominialidade do Estado sobre a área em litígio aparece sempre articulado à responsabilização deste em titular a área em favor das comunidades de fundo e fecho de pasto que dela vivem, de modo a garantir o direito das mesmas sobre seus territórios. Verifica-se também que a denúncia da grilagem tem impacto significativo na região, já que o problema vem marcando a história do oeste baiano desde a década de 1970. Em razão disso, é forte na região a carga negativa associada à imagem dos grileiros como aqueles que querem tirar vantagens passando por cima dos outros e corrompendo a estrutura do Estado.

Importa destacar que tais enquadramentos não são produto simplesmente das lógicas argumentativas das comunidades de fundo e fecho de pasto mobilizadas em torno da luta contra a grilagem e das organizações mediadoras que as apoiam em seus esforços de sensibilizar a sociedade abrangente e responsabilizar o Estado na garantia dos direitos daquelas. De acordo com Cefaï (2011), a linguagem da publicidade e da denúncia só se sustenta se baseada em sentimentos de indignação e revolta que têm a densidade do mundo da vida, os quais estão diretamente relacionados às motivações e encorajamento para a luta.

A passagem do distúrbio afetivo e moral a denuncia e ao protesto público pelos moradores do bairro assume formas diversas. O distúrbio crítico, elaborado em termos técnicos, jurídicos e políticos, somente é

40 principal impacto foi a suspensão, em consequência da proposição da discriminatória judicial de terras, de todas as ações possessórias que tramitam em relação ao conflito. sustentável se baseado em sentimentos e sensações de indignação que tem a densidade da Lebenswelt, ou seja, o mundo da vida (Cefaï, 2011, p.76)

Um indivíduo categorizado como cidadão não deixa de ser uma pessoa de carne e osso, envolvida no mundo cotidiano, de acordo com uma multiplicidade de regimes de engajamento. Essa pessoa se engaja publicamente, mas seu impulso inicial está enraizado em vulnerabilidades singulares, ínfimas humilhações, angustias indiziveis que não se deixam facilmente publicizar. A transição dos choques afetivos, sensíveis e morais aos julgamentos articulados na linguagem da publicidade, ocorre por meio da definição da situação problemática e, concomitantemente, mediante a produção de padrões de ação e formulação de boas razões para agir (Cefaï, 2011, p. 76)

Daí porque a defesa dos direitos territoriais ou das terras tradicionalmente ocupadas pelas comunidades assume centralidade nos espaços de publicização e reivindicação que foram sendo construídos na segunda fase do conflito. Tais categorias, além de encontrarem respaldo em uma série de normas do direito positivo a partir da Constituição Federal Brasileira de 1988, tentam expressar outras dimensões diretamente ligadas às motivações para a resistência e engajamento do grupo, que não aparecem na noção de direito à terra. Assim, a importância da permanência na terra não apenas por garantir as condições de subsistência material dos grupos, mas também como condição para a preservação de um modo de vida específico, para o respeito aos seus costumes e tradições, para a valorização da história de vida das comunidades, de sua relação de pertencimento com o lugar, e para a preservação do próprio gerais.

Percebe-se que a dimensão social e pública do problema também assume importância na disputa judicial, trazida para os autos pela atuação das/os advogadas/os dos trabalhadores. Em uma das principais ações judiciais que tramitam sobre o conflito (a ação de interdito proibitório), por exemplo, percebe-se que estes buscam situar o litígio no contexto de conflitos agrários da região e numa realidade de ocupação territorial específica compartilhada, há sucessivas gerações, por um conjunto de famílias e 
comunidades do local. Tal dimensão é refutada pelos fazendeiros, que buscam circunscrever o litígio a um conflito entre proprietários vizinhos, de caráter pontual e isolado e envolvendo um número restrito de pessoas.

O debate sobre a dimensão do conflito, além de estar diretamente relacionado com disputas em torno da verdade dos fatos que se operam nos processos judiciais - a partir das quais uma norma é acionada em detrimento de outra e que todas elas são interpretadas pelos advogados/as - também pode produzir implicações processuais, na medida em que possibilita que sujeitos que inicialmente não estavam no processo possam atuar no mesmo, seja na condição de fiscal da lei ou de parte interessada. Foi a partir do reconhecimento do caráter coletivo do litígio que o Ministério Público Estadual passou a acompanhar o processo já mencionado, na condição de fiscal da lei, e que dezenas de outros posseiros tiveram o direito de ingressar e se defender no processo. Nenhum dos processos chegou ao fim, mas algumas decisões tomadas no curso dos mesmos tiveram impacto significativo no desenvolvimento do conflito. Dentre tais decisões, cabe destacar as liminares concedidas em favor dos fazendeiros, proibindo as famílias das comunidades de usarem a área de uso comum, e punindo algumas delas com multa fixada em cinquenta mil reais e com o bloqueio do cadastro das mesmas junto à ADAB; e as prisões do presidente do STR e da agente da CPT. Tais decisões, em vez de inibirem o processo de organização política das comunidades e a atuação das organizações de assessoria, tiveram como consequência o fortalecimento da rede de apoio aos grupos, a ampliação da repercussão social do litígio, e a intensificação da disputa judicial - gerando condições para a cassação das decisões e a reconfiguração da correlação de forças entre os grupos envolvidos no conflito.

Nesse contexto, percebeu-se que a linguagem do direito assumiu um papel fundamental não apenas na mediação da relação dos sujeitos coletivos com o Estado, mas também com a sociedade abrangente. É, em geral, através da mesma que o Estado é convocado a intervir num conflito entre classes sociais, frações de classe ou grupos. De acordo com Cefaï (2011, p. 87) "o direito é a linguagem da publicidade por excelência. Ele possibilita uma relação de equivalência entre situações e atores sociais e fixa regras e procedimentos que balizam, previamente, o campo das ações e das interações”. Embora tal equivalência, na prática, muitas vezes, não exista, pois o direito dominante também é um instrumento de dominação ideológica de classe, sendo comumente aplicado de forma desigual e seletiva, Thompson (1987, p. 354) alerta que a condição prévia e essencial para a eficácia da lei, em sua função ideológica, é exatamente a de que mostre uma independência frente a manipulações flagrantes e pareça ser justa. Segundo este autor, tal eficácia se constrói porque a lei não se estabelece de qualquer modo, mas através de formas específicas (procedimentos) e sustentada nas noções de aplicação igual e universal que passam a regular o exercício do poder, o que faz com que haja uma significativa diferença ${ }^{5}$ entre o poder extralegal arbitrário (exercício da força sem mediação da lei) e o domínio da lei.

Ademais, o direito também pode assumir um papel importante no processo de mobilização interna de determinados grupos, contribuindo para o encorajamento e engajamento. É o caso das comunidades estudadas, as quais, sustentadas no direito costumeiro e na noção de "respeito aos costumes", vão construindo as bases para a resistência das famílias e o enfrentamento da grilagem nos locais do conflito. Tal compreensão, na segunda fase do confronto, agregou-se ao acionamento também do direito positivo, que reforça a noção do grupo de que "estão dentro de seus direitos". A partir do momento em que as comunidades passaram a ser assessoradas pela CPT, STR e AATR e a se inserir no movimento das comunidades de fundo e fecho de pasto da Bahia, ganha força a compreensão de que grilagem também representa uma situação de desrespeito ao direito positivo, não apenas em função das falsificações de documentos e do uso da violência privada para garantir o processo de expropriação territorial, mas também em função do direito das comunidades ao território e

5 Para Thompson (1987, p. 357/358) “o domínio da lei em si, a imposição de restrições efetivas ao poder e a defesa do cidadão frente às pretensões de total intromissão do poder parecem-me um bem humano incondicional, de modo que negar ou minimizar esse bem [...] significa lançar fora toda uma herança de luta pela lei e dentro das formas da lei" 
à regularização fundiária, cuja consciência emerge e se fortalece com o trabalho dos mediadores.

\section{Considerações Finais}

Tendo como referência a teoria das arenas públicas, de Cefaï (2009; 2011), o presente artigo analisou o processo de emergência e organização política das comunidades de fecho e fundo de pasto de Jacurutu e Salobro, situadas no Oeste da Bahia, contra as tentativas de expropriação e grilagem patrocinadas por fazendeiros. Verificou-se que o direito passou a assumir um lugar central na mediação da relação dos sujeitos em conflito, e no próprio processo de emergência política das comunidades de fecho e fundo de pasto. Isso se observa não apenas em função do peso que o acionamento das instâncias do Estado assumiu no confronto, mas porque foi em torno da ideia de defesa dos direitos que esses grupos foram se apresentando para o Estado e para a sociedade, e que o conflito foi se constituindo como um problema público. Isso se deu através do acionamento tanto do direito costumeiro como do direito positivo, num processo que vem envolvendo reivindicações para um progressivo reconhecimento do primeiro por parte deste último. A ideia de defesa dos direitos também assume lugar no engajamento dos sujeitos, visto que foi em torno da luta pelo respeito aos costumes que o processo de mobilização política foi iniciado.

A organização política desses grupos no âmbito estadual também é expressão desse processo. 0 reconhecimento da existência das áreas de Fundos de Pasto e Fechos de Pasto e a previsão, na Constituição Baiana de 1989, da possibilidade do estado conceder títulos coletivos de posse em favor dos seus ocupantes foi resultado de reivindicações já existentes naquele contexto pelo reconhecimento do direito costumeiro, e também se tornou um marco para a emergência do movimento das comunidades de fundo e fecho de pasto na Bahia, na medida em que a luta pela efetivação da previsão constitucional torna-se o eixo articulador de um conjunto de comunidades que viviam do pastoreio comunal no estado.

As consequências da incorporação do direito positivo no repertório de ação desses sujeitos são diversas e, muitas vezes, ambíguas. A luta pela regularização fundiária se, por um lado, tem contribuído para projetar essas comunidades no cenário político baiano e nacional, por outro, tem esbarrado em muitos problemas. As ações de regularização fundiária de fechos e fundos de pasto que vêm sendo executadas pelo Estado da Bahia, além de apresentarem um preocupante descompasso entre a emissão significativamente rápida dos títulos de domínio individuais e a criação de sucessivos obstáculos para emissão dos títulos coletivos, vêm expondo tensões e modificações na organização social dos grupos. Nas comunidades de Jacurutu e Salobro, as principais mudanças verificadas até o momento decorreram da criação das associações de fundo e fecho de pasto, que se transformaram nos principais espaços de decisão em torno dos interesses comuns. Porém, tais mudanças tendem a se ampliar com o avanço do processo de regularização fundiária e podem interferir na forma de organização do espaço, como já se verificou em outras comunidades de fundo de pasto da Bahia. São transformações como o fim da mobilidade do uso e o enrijecimento das fronteiras entre as áreas de uso familiar e de uso comum (Alcântara, 2011) e o risco das áreas individuais tituladas serem convertidas ao mercado de terra (Germani \& Oliveira, 2006). Este último aspecto vem sendo objeto de preocupação entre os membros da associação de Fundo de Pasto de Jacurutu, que vem tentando se proteger do risco com a criação - a exemplo de outras comunidades de fundo de pasto - de regras para evitar a venda de terras para pessoas de fora do grupo.

Por outro lado, o acionamento do direito positivo tem assumido um papel importante no processo de fortalecimento dos grupos para o enfrentamento à grilagem, em função da arena pública que se constituiu em torno do conflito e do impacto das decisões judiciais e administrativas tomadas com seu desenvolvimento. Os relatos dos moradores de Salobro e Jacurutu e das organizações que os apoiam dão indicativos de que a correlação de forças construída no espaço público interferiu no poder dos fazendeiros no interior da área do conflito e no prestígio social que os mesmos mantinham na cidade, obrigando-os a reduzir as ameaças e intimidações contra os moradores das comunidades. No entanto, não foram suficientes para garantir o desarmamento e retirada dos jagunços do local, o que evidencia que essa forma de 
violência pode oscilar em diferentes contextos, mas continua viva e vigilante no sertão dos gerais, em face da omissão e /ou conivência do Estado.

Importa destacar que o fortalecimento do grupo no enfrentamento à grilagem somente se verificou porque o acionamento do direito transpôs os espaços institucionais de denúncia e reivindicação para se tornar a base para um processo de sensibilização e mobilização da sociedade em geral, através de manifestações de rua, denúncias na imprensa, cartas abertas, as quais exerceram papel decisivo não apenas na construção de uma arena pública em torno do conflito, mas também de um exercício de controle social sobre a atuação das diversas instâncias do Estado.

O papel ocupado pelo direito nos conflitos sociais do campo, no Brasil, vem demonstrando que seus usos podem assumir diversas dimensões, para além da provocação das instâncias do Estado e da disputa no plano institucional. Evidencia ainda que as trincheiras históricas não desapareceram - continuam presentes nas relações com os jagunços, pistoleiros, e na luta quotidiana dos homens e mulheres que vivem do seu trabalho no campo pelo acesso aos recursos naturais, em locais de conflito. No entanto, estas convivem cada vez mais com disputas sustentadas em outro plano, o dos direitos - costumeiro e positivo. São as "trincheiras dos direitos", que não garantem a efetivação de direitos, apesar de muitas vezes reconhecê-los, mas possibilitam transportar o conflito para a arena pública, onde a política se constrói, e onde o jurídico e o político sem encontram.

11111111111111111111111111111111111

Data de submissão/Submission date: 05.09.2015. Data de aprovação/Acceptance date: 09.01.2017.

\section{Referências}

Alcântara, D. M. de (2011). Entre a forma espacial e a racionalidade jurídica: Comunidade de Fundo de Pasto da Fazenda Caldeirãzinho (Uauá-BA). Salvador, UFBA (Dissertação de mestrado em Geografia). Coordenação de Desenvolvimento Agrário (2010). Ação discriminatória Administrativa Rural: Gleba Jacurutu - Santa Maria da Vitória-BA. Salvador: CDA/SEAGRI.

Cefaï, D. (2009). Como nos mobilizamos? A contribuição de uma abordagem pragmatista para a sociologia da ação coletiva. Trad: Bruno Cardoso. Dilemas, 11-48.

Cefaï, D. (2011). Como uma associação nasce para o público: vínculos locais e arena pública em torno da associação La Bellevilleuse, em Paris. In: D. Cefaï; M. A. da S Mello; F. R. Mota; F. B. Veiga (Org.). Arenas Públicas: por uma etnografia da vida associativa (p. 67-102). Niterói: Editora da UFF.

Cohen, J. L. e Arato, A. (2000). Los movimentos sociales y la sociedad civil. In: Sociedad civil y teoria politica. México: Fondo de Cultura Economica.

Comerford, J. C., Kraychete, G. (1991). A Nova face agrária do Oeste Baiano: diversidade e ambiguidades. Cadernos do CEAS, 132, 30-51.

Germani, G.; Oliveira, G. G. de (2006). Assentamentos rurais no médio São Francisco (Bahia-Brasil): Políticas Públicas, Conflitos e Resistências. In: VII Congresso Latino-americano de Sociologia Rural. Quito. Martins, J. de S. (1980). Terra de negócio e terra de trabalho: contribuições para o estudo da questão agrária no Brasil. Cadernos do CEAS, 67, 34-44.

Medeiros, L. S. de (2012). Questões fundiárias e mediações jurídicas. In: XXX Congresso da LASA - Latin American Studies Association, 2012, San Francisco. XXX LASA Conference, 1-24.

Mendonça, R. F.; Simões, P. G. (2012). Enquadramento: diferentes operacionalizações analíticas de um conceito. Revista Brasileira de Ciências Sociais, 79 (27), 187-201.

Oliveira, N. (1983). O capitalismo no Oeste Baiano. Cadernos do CEAS, 86, 22-35.

Thompson, E. P. (1998). Costumes em Comum. Estudos sobre a cultura popular tradicional. Rev. Antônio Negro, et al. São Paulo: Companhia das Letras.

Thompson, E. P. (1987). Senhores e caçadores. São Paulo: Cia. das Letras. 